\title{
ANALISIS KESALAHAN MENYELESAIKAN SOAL PEMBUKTIAN GEOMETRI EUCLID DITINJAU DARI GENDER PADA MAHASISWA IKIP BUDI UTOMO MALANG
}

\author{
Nok I. Yazidah \\ IKIP Budi Utomo Malang \\ izatulyazidah@gmail.com
}

\begin{abstract}
ABSTRAK
Penelitian ini bertujuan untuk mendeskripsikan tentang jenis, dan penyebab kesalahan mahasiswa IKIP Budi Utomo Malang dalam menyelesaikan soal pembuktian Geometri Euclid serta pengaruh gender dalam menyelesaikan soal pembuktian tersebut. Penelitian ini merupakan penelitian deskriptif kualitatif. Metode pengumpulan data yang digunakan dalam penelitian ini meliputi: (1) tes yang digunakan untuk mengetahui letak kesalahan mahasiswa dalam menyelesaiakan soal pembuktian Geometri Euclid serta adakah pengaruh gender di dalamnya; (2) wawancara yang digunakan untuk mendapatkan data faktor penyebab kesalahan. Berdasarkan hasil penelitian kesalahan menyelesaikan soal pembuktian Geometri Euclid yang dilakukan mahasiswa IKIP Budi Utomo Malang diantaranya adalah kesalahan konseptual pada soal no 1 sebayak $32 \%$ sedangkan pada soal no 2 sebanyak $25.17 \%$, kesalahan prosedural pada soal no 1 sebayak $26,67 \%$ sedangkan pada soal no 2 sebanyak $30.83 \%$,serta kesalahan teknis hanya terjadi pada saat mengerjakan soal no 1 yaitu sebayak $0.83 \%$. Perbedaan gender pada saat menyelesaikan soal pembuktian Geometri Euclid perbedaannya tidak signifikan sehingga dapat disimpulkan bahwa tidak ada pengaruh gender dalam menyelesaikan soal pembuktian geometri Euclid. Banyak penyebab mahasiswa melakukan kesalahan dalam menyelesaikan soal-soal pembuktian Geometri Euclid salah satunya adalah mahasiswa kesulitan dalam mencari alasan pada langkah-langkah pembuktian bangun geometri.
\end{abstract}

Kata Kunci : Kesalahan, Pembuktian, Geometri Euclid, Gender.

\section{PENDAHULUAN}

Kegiatan belajar pembelajaran di dalam kelas akan lebih baik jika antara mahasiswa laki-laki dan mahasiswa perempuan dapat terlibat langsung dalam proses pembelajaran. Namun kenyataannya setiap individu memliki sifat emosional yang berbeda dalam menyerap pengetahuan yang diberikan oleh dosennya. Menurut Suseto (2006) perbedaan gender bukan hanya berpengaruh pada perbedaan kemampuan dalam matematika, tetapi berpengaruh juga pada bagaimana cara memperoleh pengetahuan matematika. Menurut Maccoby dan Jacklyn (dalam Nafi'ah, 2011) menyatakan bahwa laki-laki dan perempuan mempunyai perbedaan kemampuan antara lain sebagai berikut: (1) perempuan mempunyai kemampuan verbal lebih tinggi daripada laki-laki; (2) laki-laki lebih unggul dalam kemampuan visual spatial (penglihatan keruangan) daripada 
perempuan; (3) laki-laki lebih unggul dalam kemampuan matematika. Sedangkan menurut Setiarini dan Mubarokah (2014) menyatakan bahwa banyak ahli psikologis berpendapat bahwa laki-laki akan lebih berhasil mempelajari matematika daripada perempuan.

Menurut American Psychological Association (Science Daily, 6 Januari 2010) mengemukakan bahwa berdasarkan analisis terbaru dari penelitian internasional kemampuan perempuan di seluruh dunia dalam matematika tidak lebih buruk daripada kemampuan laki-laki meskipun laki-laki memiliki kepercayaan diri yang lebih dari perempuan dalam matematika, dan perempuan-perempuan dari negara dimana kesamaan gender telah diakui menunjukkan kemampuan yang lebih baik dalam tes matematika.

Berdasarkan hasil-hasil penelitian yang diuraikan di atas menunjukkan keberagaman hasil tentang peran gender dalam pembelajaran matematika. Ada hasil yang menunjukkan adanya pengaruh gender dalam pembelajaran matematika namun hasil penelitian yang lain juga menunjukkan bahwa gender tidak mempunyai pengaruh yang signifikan dalam pembelajaran matematika. Oleh sebab itu maka salah satu tujuan dari penulisan jurnal ini adalah untuk mendeskripsikan apakah ada pengaruh gender dalam menyelesaiakan soal pembuktian Geometri Euclid.

Pembuktian dalam matematika dirasakan sangat penting. Para ilmuwan matematika dan guru matematika keduanya sepakat tentang pentingnya pembuktian dan tentang perlunya bagi siswa untuk mengembangkan keterampilan yang dibutuhkan untuk membangun pembuktian Blaton, dkk (dalam Weber, 2004). Knuth (2002) menyatakan bahwa peranan pembuktian sangat sentral dalam pembelajaran matematika NCTM (2000) menyatakan bahwa pembuktian matematika merupakan salah satu aspek yang harus diperhatikan dalam pembelajaran matematika. Pengalaman belajar siswa pada bangku sekolah sangat mempengaruhi cara berpikir siswa pada perguruan tinggi untuk membuktikan suatu teorema dalam matematika.

Menurut Educational Development Center (Dalam Iskandar dan Adriyani, 2016) menyatakan bahwa tujuan pembuktian matematis adalah untuk: (1) menyusun fakta dengan pasti; (2) memperoleh pemahaman; (3) mengomunikasikan gagasan kepada orang lain; (4) tantangan; (5) membuat sesuatu menjadi indah; dan (6) mengkontruksi teori matematika. Bukti merupakan produk akhir dari membuktikan. Metode pembuktian diperlukan untuk menyakinkan kebenaran pernyataan atau teorema yang pada umumnya berbentuk implikasi atau biimplikasi. 
Pada pembelajaran matematika di bangku sekolah biasanya siswa tidak pernah atau jarang di ajak untuk membuktikan suatu pembuktikan misalnya dalam geometri, siswa biasanya mendapat pengetahuannya secara instan dari gurunya. Sehingga ketika di perguruan tinggi siswa dihadapkan pada sebuah pembuktian maka siswa tidak mempunyai pengalaman belajar dalam membuktikan teorema geometri dalam matematika. Moore (1994) menyatakan bahwa salah satu alasan mengapa mahasiswa menemukan kesulitan dalam pembuktian adalah pengalaman mereka dalam mengkonstruksi bukti terbatas pada geometri dasar.

Geometri adalah salah satu cakupan bidang dalam matematika yang mempunyai peran penting dalam kehidupan sehari-hari. Salah satu contohnya adalah ketika seorang ibu ingin membuat kue ulang tahun untuk anaknya dengan membandingkan loyang kotak dengan loyang bundar. Maka ibu tersebut perlu sedikit pengetahuan geometri. Ruseffendi (dalam Imswatama dan Muhassanah, 2016) menyatakan bahwa geometri ialah suatu system aksiomatik dan kumpulan generalisasi, model dan bukti tentang bentuk-bentuk benda bidang dan ruang. Walle (2001) mengemukakan alasan pentingnya mempelajari geometri diantaranya adalah: (1) geometri mampu memberikan pengetahuan yang lebih lengkap mengenai dunia; (2) eksplorasi geometri dapat mengembangkan kemampuan pemecahan masalah; (3) geometri memainkan peranan penting dalam mempelajari konsep lain dalam pembelajaran matematika; (4) geometri digunakan setiap hari oleh banyak orang; (5) geometri adalah pengajaran yang menyenangkan. Geometri bukan hanya sebuah ilmu yang dipelajari di tingkat sekolah dasar sampai menengah atas saja namun geometri juga dipelajari pada perguruan tinggi. Dalam geometri banyak sekali postulat-postulat, definisi-definisi serta teorema. Teorema-teorema tersebut harus dibuktikan sehingga kabenarannya berlaku secara umum dalam sistemnya.

Salah satu matakuliah yang memuat banyak sekali pembuktian tentang geometri adalah Geometri Euclid. Geometri Euclid merupakan mata kuliah dasar dari geometri bangun datar. Pada mata kuliah ini banyak sekali aksioma-aksioma serta definisi-definisi tentang bangun-bangun geometri. Matakuliah ini lebih banyak difokuskan pada kemampuan untuk membuktikan suatu bangun geometri dengan landasan yang kuat yang sudah mereka miliki yaitu berdasarkan aksioma, postulat, lema dan teorema itu.

Sebagai contoh membuktikan dalam geometri Euclid adalah 


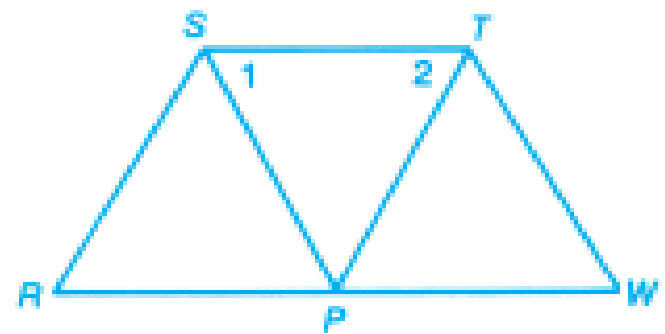

Jika diketahui $m \not R S T=m \not W T S$

$\overline{P S}$ bisector $\measuredangle R S T$

$\overline{P T}$ bisector $\measuredangle W T S$

Buktikan: $m \Varangle 1=m \Varangle 2$

Maka untuk membuktikannya pertama dari yang di ketahui $m \Varangle R S T=m \Varangle W T S$, $\overline{P S}$ bisector $\Varangle R S T$, dan $\overline{P T}$ bisector $\Varangle W T S$ maka dapat disimpulkan bahwa $m \nless 1=\frac{1}{2} m \nless R S T$ dan $m \nless 2=\frac{1}{2} m \nless W T S$ dengan menggunakan definisi dari garis bagi sudut maka dari yang diketahui dan pernyataan tersebut dapat disimpulkan $m \Varangle 1=m \nless 2$ dengan menggunakan transitif dar pernyataan $m \Varangle R S T=m \nless W T S$, (Terbukti).

Pada pembelajaran di kelas, mahasiswa sering melakukan kesalahan saat melakukan pembuktian matematis. Menurut Iskandar dan Andriyani (2016) terdapat beberapa kesalahan, antara lain kesalahan sistematis dan konsisten terjadi sebabkan oleh tingkat pengusaan materi yang kurang pada mahasiswa, sedangkan kesalahan yang bersifat incidental adalah kesalahan yang bukan merupakan akibat akibat dari rendahnya tingkat pengusaan materi, melainkan oleh sebab lain misalnya: kurang cermat dalam membaca untuk memahami maksud soal. Lebih lanjut Kiat (2005) membagi kemungkinan kesalahan yang dilakukan siswa kadalam tiga kategori, yaitu:

1) Kesalahan konseptual, yaitu kesalahan yang terjadi karena siswa tidak memahami konsep-konsep yang terlibat dalam masalah atau kesalahan yang timbul dari ketidakmampuan siswa untuk menentukan hubungan yang terlibat dalam masalah.

2) Kesalahan prosedural, yaitu kesalahan yang terjadi karena ketidakmampuan siswa untuk melakukan manipulasi atau algoritma meskipun telah memahami konsep dibalik masalah.

3) Kesalahan teknis, yaitu kesalahan yang terjadi karena kurangnya pengetahuan konten matematika dalam topik lain atau kesalahan karena kecerobohan.

Iskandar dan Andriyani (2016) menyatakan beberapa kesalahan siswa dalam menyelesaikan soal matematika antara lain yaitu:

1) Kesalahan dalam memahami soal, yang terjadi jika mahasiswa salah menentukan hal yang diketahui, ditayangkan dan tidak dapat menuliskan apa yang dikehendaki; 
2) Kesalahan dalam menentukan rumus, yang terjadi jika mahasiswa tidak mampu mengidentifikasi rumus atau metode apa yang akan digunakan atau diperlukan dalam menyelesaian soal;

3) Kesalahan dalam operasi penyelesaiannya, yang terjadi jika mahasiswa salah dalam melakukan perhitungan ataupun;

4) Kesalahan dalam menyimpulkan, yang terjadi jika mahasiswa tidak memperhatikan kembali apa yang ditayakan dari soal dan tidak membuat kesimpulan dari hasil perhitungan nya karena mahasiswa beranggapan bahwa hasil perhitungannya merupakan penyelesaian dari permasalahan yang ada.

Berdasarkan hasil observasi pada mahasiswa IKIP Budi Utomo Malang Program Studi Pendidikan Matematika dalam mengerjakan soal Geometri Euclid banyak mahasiswa mengalami kesalahan dalam pembuktiannya, serta nilai hasil pembelajarannya belum memuaskan. Oleh karena itu perlu sebuah analisis untuk mengetahui kesalahan mahasiswa dalam menyelesaikan soal pembuktian ditinjau dari gender. Analisis kesalahan ini mengacu pada jenis-jenis kesalahan yang dikemukakan oleh Kiat. Sesuai dengan latar belakang di atas, hal-hal yang ingin diuraikan dalam artikel ini yaitu sebagai berikut:

1. Jenis kesalahan apa saja yang dibuat oleh mahasiswa jurusan pendidikan matematika dalam penyelesaian soal pembuktian pada Geometri Euclid?

2. Apa penyebab terjadinya kesalahan dalam menyelesaikan soal pembuktian Geometri Euclid?

3. Apakah ada pengaruh gender dalam menyelesaian soal pembuktian Geometri Euclid? Fokus penelitian ini adalah untuk melihat kesalahan apa saja yang dilakukan mahasiswa dalam proses pembuktian matematis pada matakuliah Geometri Euclid yang di lihat dari gender. Manfaat dari penelitian ini adalah sebagai dasar atau acuan untuk pengajar atau dalam hal ini dosen dalam perkuliahan selanjutnya.

\section{METODE PENELITIAN}

Penelitian ini merupakan penelitian deskriptif kualitatif. Penelitian ini bertujuan untuk mendeskripsikan tentang jenis, dan penyebab kesalahan mahasiswa IKIP Budi Utomo Malang dalam menyelesaikan soal pembuktian Geometri Euclid serta pengaruh gender dalam menyelesaikan soal pembuktian tersebut. Subjek penelitian ini diambil 6 mahasiswa Program Studi Pendidikan Matematika yang terdiri dari 3 perempuan dan 3 
laki-laki yang menempuh matakuliah Geometri Euclid dan mempunyai kemampuan relative sama. Penelitian ini dilaksanakan di IKIP Budi Utomo Malang.

Instrument yang digunakan dalam penelitian ini adalah tes tertulis bentuk uraian. Hal ini didasarkan pada pertimbangan bahwa tes ini menuntut kemampuan mahasiswa untuk dapat menghubungkan pengetahuan yang telah mereka peroleh untuk menyelesaiakan masalah pembuktian Geometri Euclid. Menurut Arikunto (2010) bahwa salah satu kelebihan dari bentuk tes uraian adalah dapat diketahui sejauh mana mahasiswa mendalami suatu masalah yang diteskan. tes tersebut memuat soal pembuktian tentang bangun-bangun geometri

Metode pengumpulan data yang digunakan dalam penelitian ini meliputi: (1) tes yang digunakan untuk mengetahui letak kesalahan mahasiswa dalam menyelesaiakan soal pembuktian Geometri Euclid serta adakah pengaruh gender di dalamnya; (2) wawancara yang digunakan untuk mendapatkan data factor penyebab kesalahan.

\section{HASIL PENELITIAN DAN PEMBAHASAN}

Hasil tes akan dideskripsikan dalam bentuk persentase kesalahan yang dilakukan mahasiswa, yang berupa pembuktian bangun-bangun geometri pada matakuliah Geometri Euclid.

Tabel 1. Presentasi Kesalahan

\begin{tabular}{|c|c|c|c|c|c|c|c|c|}
\hline \multirow[t]{3}{*}{ Mahasiswa } & \multicolumn{6}{|c|}{ Jenis Kesalahan } & \multirow{3}{*}{$\begin{array}{c}\text { Jumlah } \\
\text { kesalahan } \\
\text { yang } \\
\text { dilakukan } \\
\text { oleh } \\
\text { mahasiswa }\end{array}$} & \multirow{3}{*}{$\begin{array}{c}\text { Rata-rata } \\
\text { Kesalaha } \\
\text { n } \\
\text { Mahasis } \\
\text { wa }\end{array}$} \\
\hline & \multicolumn{2}{|c|}{$\begin{array}{l}\text { Kesalahan } \\
\text { Konseptual }\end{array}$} & \multicolumn{2}{|c|}{$\begin{array}{l}\text { Kesalahan } \\
\text { Prosedural }\end{array}$} & \multicolumn{2}{|c|}{$\begin{array}{l}\text { Kesalahan } \\
\text { Teknis }\end{array}$} & & \\
\hline & $\begin{array}{l}\text { Soal No } \\
1\end{array}$ & $\begin{array}{ll}\text { Soal No } \\
2\end{array}$ & $\begin{array}{l}\text { Soal No } \\
1\end{array}$ & $\begin{array}{l}\text { Soal No } \\
2\end{array}$ & $\begin{array}{l}\text { Soal } \\
\text { No } 1\end{array}$ & $\begin{array}{l}\text { Soal } \\
\text { No } 2\end{array}$ & & \\
\hline LK 1 & $62 \%$ & $30 \%$ & $33 \%$ & 0 & 0 & 0 & $125 \%$ & $20 \%$ \\
\hline PR 1 & $33 \%$ & 0 & $44 \%$ & $25 \%$ & 0 & 0 & $102 \%$ & $17 \%$ \\
\hline LK 2 & 0 & $39 \%$ & $35 \%$ & $40 \%$ & 0 & 0 & $114 \%$ & $19 \%$ \\
\hline PR 2 & $43 \%$ & 0 & 0 & $63 \%$ & 0 & 0 & $106 \%$ & $17,67 \%$ \\
\hline LK 3 & $32 \%$ & $50 \%$ & $23 \%$ & $27 \%$ & 0 & 0 & $132 \%$ & $22 \%$ \\
\hline PR 3 & $27 \%$ & $32 \%$ & $25 \%$ & $30 \%$ & $5 \%$ & 0 & $119 \%$ & $19.83 \%$ \\
\hline Jumlah & $197 \%$ & $151 \%$ & $160 \%$ & $185 \%$ & $5 \%$ & 0 & & \\
\hline Rata-rata & $32 \%$ & $25.17 \%$ & $26,67 \%$ & $30.83 \%$ & $0.83 \%$ & 0 & & \\
\hline
\end{tabular}

Dari tabel 1 terlihat bahwa presentase kesalahan yang dilakukan mahasiswa prodi pendidikan matematika dalam menyelesaikan 2 soal geometri adalah pada kesalahan konseptual, kesalahan procedural dan kesalahan teknis. Namun mahasiswa lebih cenderung melakukan kesalahan konseptual dan kesalahan procedural, terlihat dari hasil rata-rata yang mahasiswa peroleh menunjukkan bahwa pada saat mengerjakan soal no 1 kesalahan yang paling banyak adalah kesalahan konseptual dengan nilai rata-rata 32\%, sedangkan 
pada saat mengerjakan soal no 2 kesalahan yang paling banyak adalah kesalahan procedural dengan nilai rata-rata $30.83 \%$. Kesalahan konseptual yang sering dilakukan mahasiswa adalah ketika mahasiswa sudah mengerjakan setiap langkahnya benar namun ada alasan yang masih kurang tepat. Sedangkan kesalahan procedural adalah ketika mahasiswa sudah mengerti tujuannya tetapi tidak tahu langkah-langkahnya.

Berikut adalah hasil dari pekerjaan mahasiswa dalam menyelesaikan soal pembuktian Geometri Euclid:

1. Kesalahan Konseptual

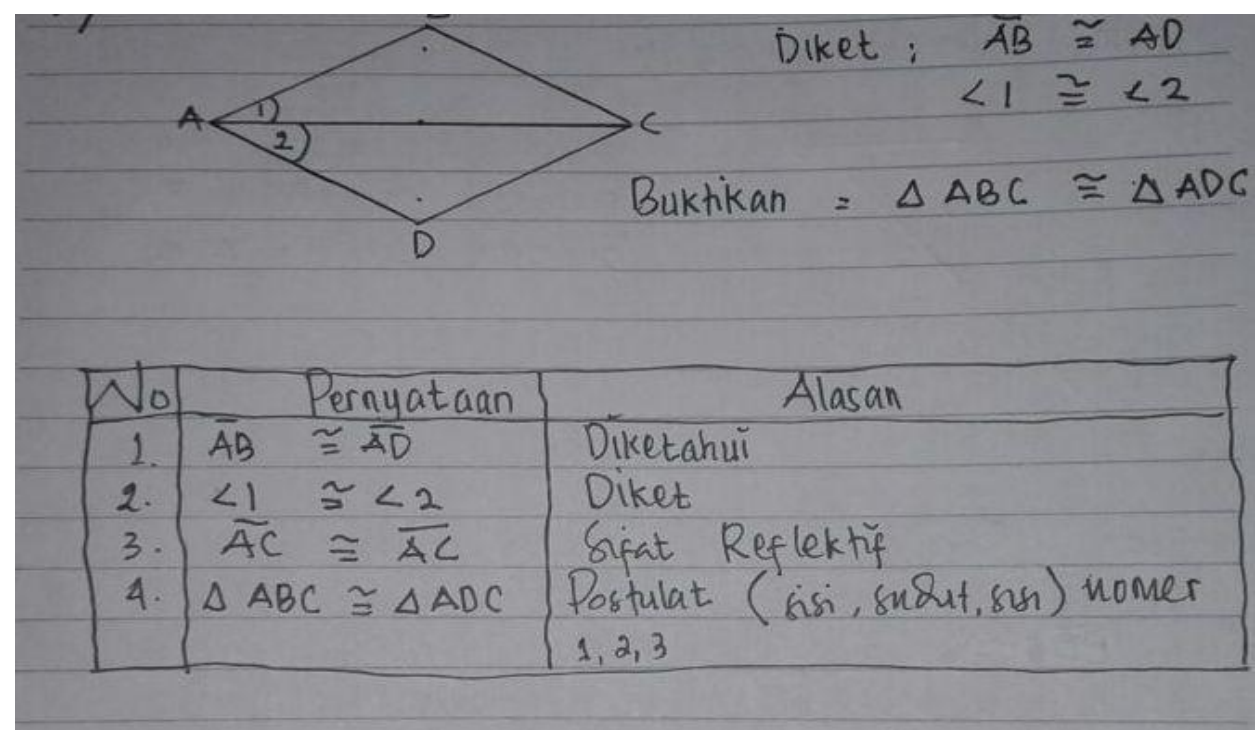

Gambar 1. Contoh Kesalahan Konseptual

Pada langkah no 3 mahasiswa kurang tepat dalam menuliskan alasannya, seharusnya jawaban yang benar adalah sifat reflektif kongruensi ruas garis.

2. Kesalahan Prosedural

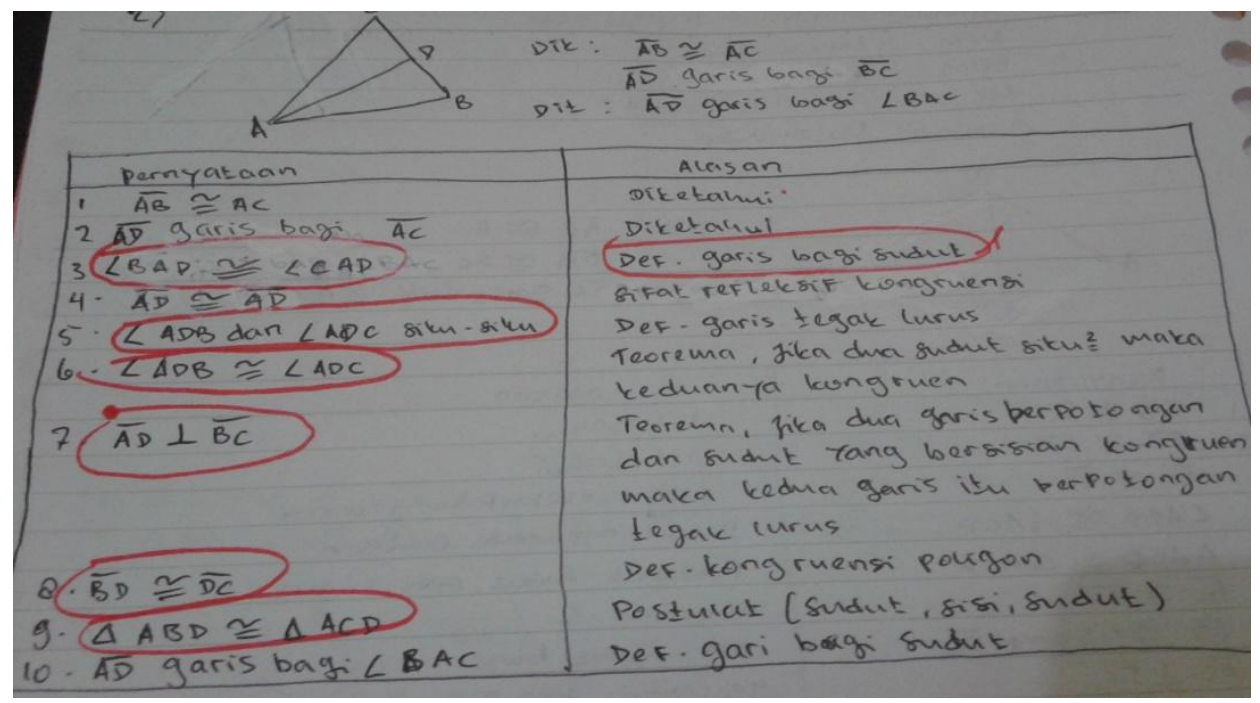

Gambar 2. Contoh Kesalahan Prosedural 
Dari gambar 2 terlihat bahwa mahasiswa sudah mengetahui tujuan dari pembuktiannya namun mahasiswa tidak bisa menemukan langkah-langkah yang harus ditempuh agar mencapai tujuan pembuktiannnya. Langkah-langkah tersebut harusnya adalah sebagaimana tabel 2 berikut:

Tabel 2. Langkah-langkah Pembuktian yang Dituju

\begin{tabular}{|c|c|c|}
\hline No & Pernyataan & Alasan \\
\hline 1. & $\overline{A B} \cong \overline{A C}$ & Diketahui \\
\hline 2. & $\overline{A D}$ garis bagi $\overline{\overline{B C}}$ & Diketahui \\
\hline 3. & $\overline{B D} \cong \overline{\overline{C D}}$ & Definisi garis bagi \\
\hline 4. & $\overline{A D} \cong \overline{\overline{A D}}$ & Sifat Refleksi kongruensi ruas garis \\
\hline 5. & $\triangle A B D \cong \triangle A C D$ & $\begin{array}{l}\text { Dari } 1,3,4 \text { dan teorema } 2 \text { segitiga adalah kongruen jika ada korespondensi antara } \\
\text { titik-titik sudutnya dan ketiga sisi-sisi segitiga yang satu kongruen dengan ketiga } \\
\text { sisi yang berkorespondensi dari segitiga yang lain (sisi, sisi, sisi) }\end{array}$ \\
\hline 6. & $\angle B A D \cong \angle C A D$ & Definisi kongruensi segitiga \\
\hline 7. & $\overline{A D}$ garis bagi $\angle B A C$ & Definisi garis bagi sudut \\
\hline
\end{tabular}

3. Kesalahan Teknis

Dalam pengerjaan soal-soal yang telah diberikan, salah satu mahasiswa hanya mengalami sedikit kesalahan teknis. Yaitu mahasiswa hanya melakukan kesalahan pada saat menuliskan pernyataan namun alasannya benar.

Hasil wawancara dengan mahasiswa menunjukkan bahwa penyebab terjadinya kesalahan mahasiswa dalam menyelesaikan soal-soal Geometri Euclid adalah sebagai berikut:

1. Pemahaman awal mahasiswa tentang bangung-bangun geometri masih lemah, misalnya adalah mahasiswa masih menganggap bahwa persegi dan persegipanjang bukan jajargenjang padahal persegi, persegipanjang, jajargenjang itu termasuk dalam jajargenjang.

2. Mahasiswa tidak hafal semua postulat, definisi dan teorema untuk membuktikan bangun-bangun geometri tersebut,

3. Mahasiswa kesulitan dalam mencari alasan pada langkah-langkah pembuktian bangun geometri,

4. Mahasiswa hanya terpaku pada contoh yang telah diberikan sebelumnya jadi ketika dihadapkan pada soal berbeda mahasiswa merasa kebingungan apa yang harus dilakukan,

5. Mahasiswa kurang teliti dalam menyusun langkah-langkah untuk mencapai tujuan yang ingin dibuktikan, 
6. Kurang aktifnya mahasiswa dalam bertanya jika mengalami kebingung pada saat mengerjakan latihan,

7. Kurangnya latihan yang dilakukan oleh mahasiswa sehingga pengalaman dalam mengerjakan soal yang lebih susah merasa kesulitan,

8. Kurang cermatnya mahasiswa dalam mengerjakan soal pembuktian tersebut sehingga menimbulkan kesalahan,

9. Kurang tepatnya cara belajar yang dilakukan oleh mahasiswa.

Salah satu tujuan dari penelitian ini adalah untuk memberikan gambaran apakah ada pengaruh gender pada saat menyelesaikan soal pembuktian Geometri Euclid. Hasil yang diperoleh yang telah dipaparkan pada tabel 1 menunjukkan memang adanya perbedaan tingkat kesalahan yang dilakukan oleh mahasiswa, misal antara LK 1 (laki-laki 1) dengan PR 1 (Perempuan 1) tingkat kesalahn yang dilakukan hanya berbeda $3 \%$ dalam menyelesaikan soal pembuktian Geometri Euclid, namun perbedaan tersebut tidak signifikan karena masing-masing subyek mengalami kesalahan yang sama, dan masih dalam taraf wajar. Dengan demikian perbedaan antara laki-laki dan perempuan dalam menyelesaikan soal pembuktian Geometri Euclid tidak memberikan bukti bahwa salah satunya akan menyelesaikan soal pembuktian dengan baik. Hal ini sesuai dengan penelitian yang telah dilakukan oleh American Psychological Association.

\section{PENUTUP}

Berdasarkan hasil penelitian dan pembahasan dapat disimpulkan bahwa:

1. Kesalahan menyelesaikan soal pembuktian Geometri Euclid yang dilakukan mahasiswa IKIP Budi Utomo Malang diantaranya adalah

a. Kesalahan konseptual pada soal no 1 sebayak $32 \%$ sedangkan pada soal no 2 sebanyak $25.17 \%$.

b. Kesalahan prosedural pada soal no 1 sebayak $26,67 \%$ sedangkan pada soal no 2 sebanyak $30.83 \%$

c. Kesalahan teknis hanya terjadi pada saat mengerjakan soal no 1 yaitu sebayak $0.83 \%$.

2. Banyak penyebab mahasiswa melakukan kesalahan dalam menyelesaikan soal-soal pembeuktian Geometri Euclid salah satunya adalah mahasiswa kesulitan dalam mencari alasan pada langkah-langkah pembuktian bangun geometri 
3. Perbedaan gender pada saat menyelesaikan soal pembuktian Geometri Euclid perbedaannya tidak signifikan sehingga dapat disimpulkan bahwa tidak ada pengaruh gender dalam menyelesaikan soal pembuktian geometri Euclid.

\section{REFERENSI}

American Psychological Association. (2010). Few Gender Differences in Math Abilities, Worldwide Study Finds. Diperoleh dari https://www.sciencedaily.com/releases/2010/01/100105112303.htm (2017, 9 Januari).

Arikunto, S. (2010). Prosedur Penelitian. Jakarta: Rineka Cipta.

Imswatama, A. \& Muhassanah, N. (2016). Analisis Kesalahan Mahasiswa dalam Menyelesaikan Soal Geometri Analitik Bidang Materi Garis dan Lingkaran. Suska Journal of Mathematiccs Education, 2(1), 1-12.

Iskandar, R.S.F. \& Andriyani, R. (2016). Analisis Kesalahan Pembuktian Matematis Mahasiswa pada Matakuliah Analisis Real. Proseding Seminar Nasional Pendidikan Matematika dengan tema "Pengembangan 4C's dalam Pembelajaran Matematika: Sebuah Tantangan dalam Pengembangan Kurikulum Matematika" pada tanggal 28 Mei 2016 di prodi Pendidikan Matematika Pascasarjana Universitas Negeri Malang.

Kiat, S.E. (2005). Analysis of Students' Difficulties in Solving Integration Problem. The Mathematics Educator, 9(1), 39-59.

Knuth, E. (2002). Secondary school Mathematics Teachers' Conception of Proof. Journal for Reserch in Mathematics Education, 33(5), 379-405

Moore, R.C. (1994). Making the Transition to Formal Proof. Educational Studies in Mathematics.

Nafi'ah, M.I. (2011). Kemampuan Siswa dalam Menyelesaiakan Soal Cerita Ditinjau dari Gender di Sekolah Dasar. Proseding. Seminar Nasional Matematika dan Pendidikan Matematika dengan Tema "Matematika dan Pendidikan Karakter dalam Pembelajaran" ISBN : 978-979-16353-6-3.

National Council of Teachers of Mathematics (Ed.). (2000). Principles and standards for school mathematics (Vol. 1). National Council of Teachers of Mathematics.

Setiarini, E.H. \& Mubarokah, L. (2014). Hasil Analisis Pemahaman Geometri Siswa Berdasarkan Jenis Kelamin. Jurnal Pendidikan Matematika STKIP PGRI Sidoarjo. 2(1).

Suseto. (2006). Mekanisme Interaksi antara Pengalaman Kultural-matematis, Proses Kognitif, dan Topangan dalam Reivensi Terbimbing. Disertasi. Surabaya: Universitas Negeri Surabaya

Walle, J.A. (2001). Geometric Thingking and Geometri Concepts. In Elementary and Middle School. Mathe-matics: Teaching developmentally, 4th ed. Boston: Allyn and Bacon

Weber, K. (2004). A Framework For Describing The Processes That Undergraduates Use To Construct Proofs. Proceedings of the 28th Conference of The International group for the Psychology of Mathematics Education. Vol 4, 425-423. 